\title{
Conflict management of water resources in the Sefidrud River Basin of Iran
}

\author{
K. Nagata ${ }^{1}$, M. Sayyari ${ }^{2}$, M. Inaoka ${ }^{1} \&$ M. Yajima ${ }^{3}$ \\ ${ }^{I}$ Japan International Cooperation Agency (JICA), Japan \\ ${ }^{2}$ Water Resources Management Company, Ministry of Energy, Iran \\ ${ }^{3}$ CTI Engineering International Co., Ltd, Japan
}

\begin{abstract}
Sefidrud River is one of the largest rivers in Iran and its basin extends mainly into seven (7) provinces, where typical water resources conflicts exist between the lower and upper reaches as well as between existing and future water rights. It is of the urgent needs for balanced economic development in the basin to mitigate the conflicts and to realize integrated water resources development and management. This paper reports the progress and result of conflict management among the relevant provinces. Firstly the background of the conflict was clarified and the clues to solutions were analyzed from the viewpoint of water use rights, equity/social justice, economic efficiency and reliability of data and information. Secondly, a collaborative and win-win approach was proposed and applied to the conflict management. Finally some direction toward a conflict solution and realization of the IWRM concept was proposed for the provinces.

Keywords: water resources, water right, conflict management, IWRM, Iran.
\end{abstract}

\section{Introduction}

The Islamic Republic of Iran is characterized by its extremely unequallydistributed water resources: Annual mean precipitation is $250 \mathrm{~mm}$ while available per capita water resources are $1,900 \mathrm{~m}^{3} /$ year, which is about a quarter of the world mean value. On the other hand, the water demands have been increasing due to rapid growth of agriculture, industry and population.

The Sefidrud River with the large tributaries of Gezelozen and Shahrud Rivers is one of the foremost rivers in Iran, and is located in the northwestern part of the country. Its basin extends mainly into seven (7) provinces having the 
total drainage area of $59,090 \mathrm{~km}^{2}$ with the population of 4.72 million people in 2006. The annual average precipitation is $346 \mathrm{mmin}$ the whole basin, more than $1,000 \mathrm{~mm}$ in the northern part between the Caspian Sea and Albultz Range. Meanwhile precipitation in the southern part is from $200 \mathrm{~mm}$ to $400 \mathrm{~mm}$, more than $90 \%$ of which occurs during the seven months between November and May.

Gilan Province located in the most downstream has the primary paddy fields in the country, requiring a huge amount of irrigation water, which depends mostly on Manjil Dam in Sefidrud River. The upper reaches of the Shahrud River basin are within Tehran and are expected to be the main water source for the Tehran Metropolitan area. However, the upper-reach provinces of Gezelozen River also require water for economic and agricultural development, and the water resources development is being planned without coordination among the other provinces. Hereby, the severe water resources conflict among the relevant provinces has emerged and is hindering proper water resources management. It is a pressing issue to mitigate the conflict and to plan the optimum allocation and efficient use of water resources in full consideration of the entire basin.

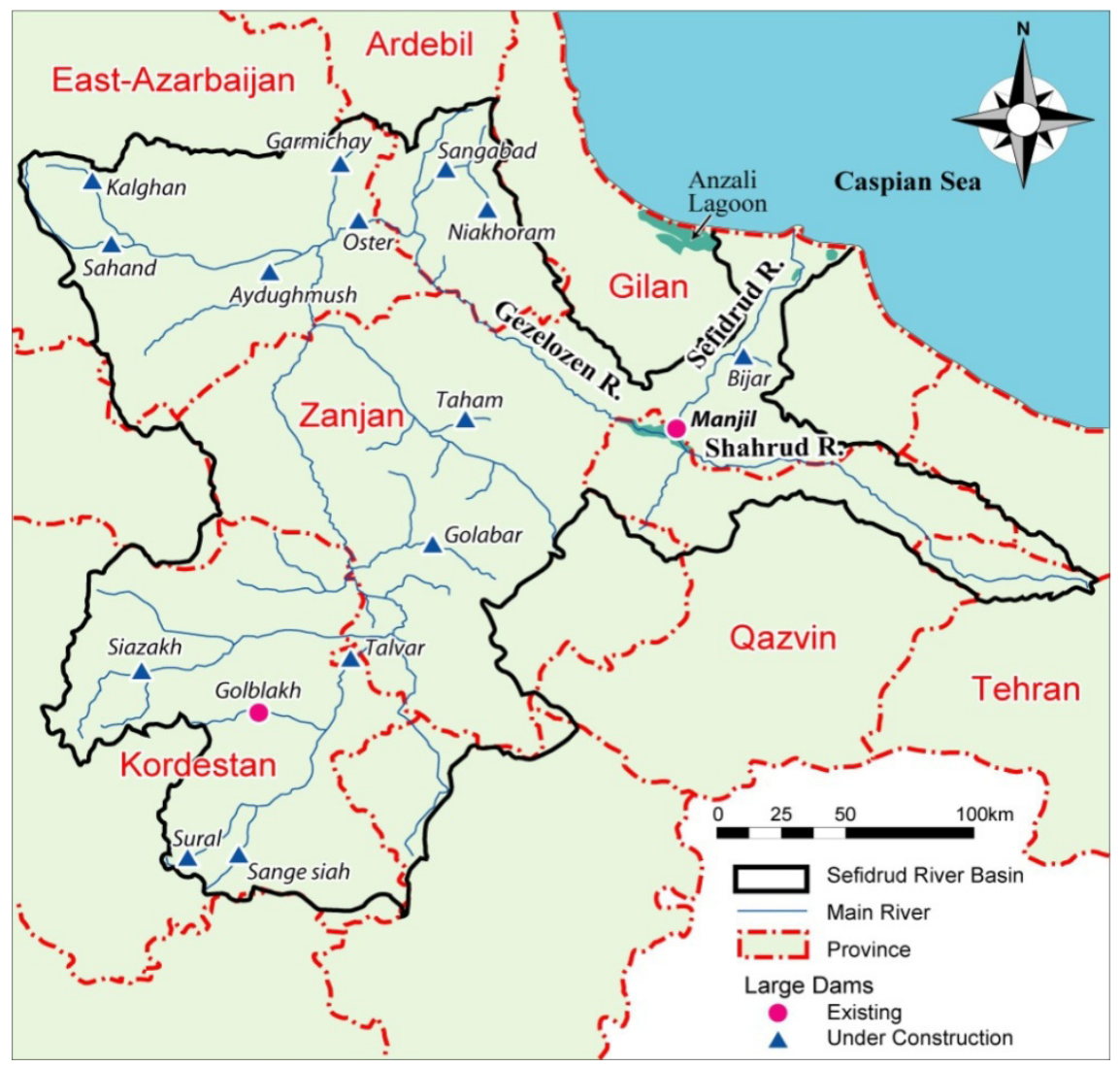

Figure 1: $\quad$ Sefidrud River Basin and relevant provinces [1]. 


\section{Concept of conflict management}

In the Sefidrud River basin, typical water resources conflicts are found between the upper and lower reaches as well as between existing and future water rights.

The Oxford Dictionary defines "conflict" as a situation in which people, groups or countries are involved in a serious disagreement or argument. Suzuki [2] explains two faces of a conflict. The negative one is to worsen problems on the conflict if left as it is. The positive one is to deepen finding and understanding of others, to find and implement more creative and better measures, and to build up strong human relations and improve morals. Conflict management is to cope with a conflict keeping the positive face and minimizing the negative face. To manage a conflict, a collaborative approach has to be taken rather than a competitive approach to create an integrated and win-win solution. Stakeholders can foster confidence each other through cooperative communication and then build up an idea of creative solutions.

There are various stakeholders such as individuals, groups, villages, districts, the state and donors from the standpoint of different level [3]. Stakeholders of the water sector can be classified into sub-sectors such as irrigation, municipal, industrial, and environmental waters. The stakeholders can also be classified regional-wise such as upper and lower reaches. It shall be easy to solve problems if all stakeholders could tackle problems with a common purpose. However in many cases, the stakeholders' interests and concerns opposing each other are actually the main cause of the problems.

Differences of stakeholders and their interests are often the origin of conflicts. As each stakeholder insists on his/her values, objectives, viewpoints, profits and thoughts, conflicts are originated and it makes the solution of the conflicts difficult. Therefore, the first step to a conflict solution is mutual understanding of stakeholders through communication. It should be noted that not only information but also context (background of each stakeholder) which exist behind the conflict should be shared among all the stakeholders in this communication[4].This is why conflict analysis that grasps the background of the stakeholders is indispensable for conflict management.

\section{Study approaches}

Water resources are becoming scarce more and more due to demand increase accompanied with economic and social development. Historically in the world, water conflicts have been occurring between upper and lower reaches or between urban and rural areas, as well as between existing and future water users. Such conflicts have been coordinated with concluding agreements or promoting integrated water resources management (IWRM). Considering such general background of water resources management, the following approach is applied to the study, frequently holding stakeholder meetings, workshops and local consultations with relevant organizations, water users and stakeholders:

1) Evaluate water resources potential of the Sefidrud River basin and water demands of the related provinces; 
2) Grasp the background of the conflicts among stakeholders through the discussions, and analyze the conflicts;

3) Discuss actual conditions and solutions of the conflict among stakeholders;

4) Discuss collaborative and win-win approaches for conflict management, and clarify them; and

5) Propose a principle of water resources development and management in the Sefidrud River basin.

\section{Water resources conflict among the related provinces}

\subsection{Background of the related provinces}

The related seven (7) provinces can be geographically divided into three (3) groups, namely 1) the upper-reach group consisting of the provinces of EastAzarbaijan, Ardebil, Kordestan and Zanjan, 2) Gilan Province which is located in the lower reaches, and 3) the other provinces of Qazvin and Tehran. The provincesof the upper-reach group have the common characteristics about ethnicity and languages, where non-Persian speaking ethnicities including Azarbaijani or Kurdish share the majorities with their natural characteristics such as highlands or mountainous areas. On the other hand, Persian speaking ethnicities share the majority in the other provinces. The characteristics of the related provinces are summarized in Table 1.

Table 1: $\quad$ Grouping of the related provinces in the Sefidrud River Basin.

\begin{tabular}{|c|c|c|c|c|}
\hline \multicolumn{2}{|c|}{ Characteristics } & \multirow{2}{*}{$\begin{array}{c}\begin{array}{c}\text { Overwhelming in } \\
\text { agriculture and } \\
\text { stock raising }\end{array} \\
\begin{array}{c}\text { Ardebil, } \\
\text { Kordestan, Zanjan }\end{array}\end{array}$} & \multirow{2}{*}{\multicolumn{2}{|c|}{$\begin{array}{c}\begin{array}{c}\text { Industries and } \\
\text { commerce } \\
\text { developed }\end{array} \\
\text { East-Azarbaijan }\end{array}$}} \\
\hline $\begin{array}{l}\text { Majority is non-Persian } \\
\text { speaking ethnicities }\end{array}$ & Upper Reaches & & & \\
\hline \multirow{2}{*}{$\begin{array}{l}\text { Majority is Persian } \\
\text { speaking ethnicities }\end{array}$} & Lower Reaches & Gilan & & - \\
\hline & Others & Q & & Tehran \\
\hline
\end{tabular}

The upper-reach group can be also divided into East-Azarbaijan where industries and commerce have relatively developed, and the provinces where agriculture and stock raising are dominant, including Ardebil, Kordestan and Zanjan. The non-upper reaches can be divided into Gilan where agricultural production, especially rice is highly large, Tehran where industry is overwhelming, and Qazvin which is located between of the two.

Gilan Province shows some distinguishable characteristics among the provinces. It is located in the lowest reaches, and in the largest production area of rice that is a principal food and a national strategic agricultural product of Iran.

According to recent reorganization of Iranian high level water resources management, new Regional Water Authorities/Companies were established in some provinces in the basin, and each province has its own water authority. Before then, water resources in Ardebil, Kordestan and Qazvin had been 
managed by nearby provincial water authorities. Under the circumstances, the newly established water authorities believe their own rights in water resources development, and do not appreciate the background of the area honestly or legitimately. Moreover, Kordestan, which is a border province, had missed development opportunities during the Iran-Iraq war, and is claiming more water as their basic right over recent periods. The central government needs prudence on deciding a policy on water resources, and it should satisfy all the provinces.

\subsection{Conflict analysis}

The provinces in the upper reaches require water allocation based on the potential of future development on one hand. The lower-reach province expresses that the existing use of water should be highly esteemed on the other hand. The confrontation about the water allocation is clarified in this point. Tehran and Qazvin stand and see the confrontation since they have different topographical conditions and are conventionally prioritized in water allocation. Key points of such conflict can be analysed as shown in Table 2.

If the upper-reach provinces develop water resources without any consideration to the downstream, the inflow to Manjil Dam would reduce and the irrigation water would also reduce. And then, it is quite obvious that the agricultural production would decrease in the lower-reach province of Gilan.

Table 2: Conflict analysis on water resources in the Sefidrud River Basin.

Core conflict: Water allocation between the upper-reach and lower-reach provinces

\begin{tabular}{|c|l|l|}
\hline $\begin{array}{c}\text { Key points of } \\
\text { conflict }\end{array}$ & \multicolumn{1}{c|}{$\begin{array}{c}\text { Claim of } \\
\text { the upper-reach provinces }\end{array}$} & \multicolumn{1}{c|}{$\begin{array}{c}\text { Claim of } \\
\text { the lower-reach province }\end{array}$} \\
\hline \hline $\begin{array}{c}\text { 1. Rights of } \\
\text { water use }\end{array}$ & $\begin{array}{l}\text { Those who have water sources } \\
\text { have the right to use the water } \\
\text { primarily. }\end{array}$ & $\begin{array}{l}\text { Those who have been using the } \\
\text { water for more than 40 years } \\
\text { have the vested water rights. }\end{array}$ \\
\hline $\begin{array}{l}\text { 2. Equity and } \\
\text { social justice }\end{array}$ & $\begin{array}{l}\text { It is equitable to increase the } \\
\text { income in the upper reaches by } \\
\text { developing agriculture/industry } \\
\text { since their income is lower than } \\
\text { the national average. }\end{array}$ & $\begin{array}{l}\text { The income of the farmers in } \\
\text { the lower-reach province has } \\
\text { already decreased due to water } \\
\text { shortage. Further decrease of } \\
\text { the income would lead to social } \\
\text { unrest. }\end{array}$ \\
\hline $\begin{array}{l}\text { 3. Economic } \\
\text { efficiency }\end{array}$ & $\begin{array}{l}\text { The land in the upper-reach } \\
\text { areas is fertile and has potential } \\
\text { for development. One of main } \\
\text { products is alfalfa, which can } \\
\text { earn } 22.78 \text { million Rials/ha. } \\
\text { Water use is inefficient in the } \\
\text { lower-reach areas. }\end{array}$ & $\begin{array}{l}\text { The lower-reach areas are the } \\
\text { optimum land for producing } \\
\text { rice, which is a national } \\
\text { strategic agricultural product, } \\
\text { and earn 0.57 million Rials/ha. }\end{array}$ \\
\hline $\begin{array}{l}\text { 4. Reliability of } \\
\text { data and } \\
\text { information }\end{array}$ & $\begin{array}{l}\text { Data and information provided } \\
\text { by the lower-reach province are } \\
\text { not reliable. }\end{array}$ & $\begin{array}{l}\text { Data and information provided } \\
\text { by the upper-reach provinces } \\
\text { are not reliable. }\end{array}$ \\
\hline
\end{tabular}


It is also concerned that water quality in the lower reaches would degrade due to the reduction of river flow in the lower reaches. The water quality problem, however, would be considered less serious comparing to the water allocation problem for the time being. Sedimentation in Manjil Dam is a serious problem, however sedimentation in the rivers is not recognized so much as a problem as water allocation among the provinces.

As a result of the conflict analysis, it has been clarified that the provinces do not take cooperative actions because they believe that water resources are not fairly allocated among them. The reasons of the unfairness are: 1) Each province insists different criteria of the fairness to justify its argument; and 2) Each province has some mistrust in other provinces therefore cannot accept the argument of other provinces.

\section{Consideration of conflict solution}

\subsection{UN convention and its application to the Sefidrud river basin}

The 1997 United Nations Convention on the Law of the Non-Navigational Uses of International Watercourses is not yet in force but is the only treaty governing shared freshwater resources with universal applicability. It stipulates the following principles for the utilization of water in an international river:1) Equitable and reasonable utilization (Article 5), 2) Participation in utilization (Article 5), 3) Obligation not to cause significant harm (Compensation shall be made if significant harm is caused.) (Article 7), 4) Promotion of cooperation among related countries (Article 8), and 5) Regular exchange of data and information (Article 10). It might be said that Principles 2) to 5) are the means for securing Principle 1) in effect.

Principle 1) is always questioned about the confrontation with Principle 3). It is a typical case that water resources development in the upper reaches based on the request of equity affects the flow of the lower reaches. Although it was disputed in the course of drafting the 1997 UN Convention which should be prioritized between Principles 1) and 3), the final settlement was that either one can be prioritized case by case. Prof. Stephen McCaffrey [5] views that the conditions such as compensation for Principle 3) result in that Principle 1) shall be prioritized. Therefore, pursuing equity can be preferred to vested rights with fulfilling the conditions such as compensation from the viewpoint of Prof. McCaffrey [5].

The "equity" does not mean a pro forma equality, but can be defined as a balanced situation where conditions of each country are taken into consideration. In terms of water utilization, it does not require that each country use the equal amount of water, but that each country can utilize a certain amount of water based on its conditions. The 1997 UN Convention requires taking into account all relevant factors and circumstances, including (Article 6): a) Natural conditions such as geography, hydrology, climate, etc. b) Social and economic needs, c) Population, d) Effects of water use, e) Existing and potential water 
uses, f) Cost of conservation, protection, development and economic use, and g) Availability of alternatives.

The 1997 UN Convention shall be a good reference for the coordination of the rights on water use among the provinces located in the Sefidrud River basin. In fact, many of the above mentioned factors were presented and discussed in the workshops of the stakeholder analysis.

\subsection{Consideration of equity}

\subsubsection{Equity under constraints}

Various constraints of water utilization need to be considered when equitable water allocation is being discussed, such as depletion of water resources, deterioration of environment, national policies, etc. This is why Article 5 of the 1997 UN Convention also requires "reasonableness".

In the case of Sefidrud Basin, outcomes of the workshops have identified the constraints as both the environmental objectives, namely sustainability on water resources potential, water environment, etc. and the national objectives, namely national policies on water resources and strategic agricultural products.

\subsubsection{Indicators of equity}

Some indicators need to be used for the evaluation of equity. Evaluation results will differ depending on the selection of evaluation indicators. Equity of water allocation can change in accordance with the employment of the indicators. The 1997 UN Convention shows the factors relevant to equitable and reasonable utilization, but does not stipulate the priority of the factors.

In the case of Sefidrud Basin, the indicators proposed in the workshops were categorized into: 1) water demand, 2) water supply potential, 3) economic efficiency of water use, 4) conformity to the national policy, 5) social and economic impacts, 6) environmental consideration, and 7) others. Categories 4) and 6) are considered to be the constraint conditions of sustainable water use. The basin size that falls in a province, for example, is an indicator of Category 2) but this might not be suitable from the viewpoint of IWRM since it would not be agreeable by the upper and lower reaches. Category 5) is not easy to quantify. On the other hand, Categories 1) and 3) can be quantified and would become representative indicators for the evaluation of equity in the basin.

\subsection{Clue to conflict solution}

\subsubsection{Right of water use}

There is no objectively correct answer to the confrontation of water right between the future development in the upper reaches and the existing investments in the lower reaches. It can be considered unproductive to continue such direct confrontation without any progress. Therefore, this issue should be put aside and facilitation is necessary so that all the parties start discussions with the aim of improving each of their present situations as much as possible. However, as the ideas to unilaterally reduce the present water allocation in the lower reaches shall not be accepted by them, compensation measures in Table 3 may be taken into consideration. 
Table 3: $\quad$ Alternatives of compensation measures.

\begin{tabular}{|l|l|}
\hline \multicolumn{1}{|c|}{ Measures } & \multicolumn{1}{c|}{ Alternatives of compensation measures } \\
\hline \hline $\begin{array}{l}\text { Substantive } \\
\text { conservation } \\
\text { of the present } \\
\text { water } \\
\text { allocation }\end{array}$ & $\begin{array}{l}\text { - Preserve the equal amount of production with less water by } \\
\text { implementing projects such as improving irrigation efficiency } \\
\text { - Introduce kinds of crops or cropping methods that require less } \\
\text { water and preserve the equal income } \\
\text { - Implement water resources development with no significant harm } \\
\text { to the other provinces }\end{array}$ \\
\hline $\begin{array}{l}\text { Covering the } \\
\text { reduction of } \\
\text { water and } \\
\text { yield with } \\
\text { other forms }\end{array}$ & $\begin{array}{l}\text { - Provide subsidies from the national treasury } \\
\text { - Promote public works and industries to create employment and } \\
\text { cover the reduction of the income }\end{array}$ \\
& $\begin{array}{l}\text { Levy water charge to the more economically efficient areas (the } \\
\text { upper reaches) and subsidize it to the other areas (the lower } \\
\text { reaches) }\end{array}$ \\
\hline
\end{tabular}

\subsubsection{Equity and social justice}

The purpose of establishing equity among the relevant provinces is not to attain a pro forma equality but to achieve social justice. The confrontation comes about because each province insists its own justice only. There is necessity that all the provinces consent to solutions with each other.

\subsubsection{Economic efficiency}

The scope where the criterion for the claims is applied is different each other since the upper-reach provinces apply it within the river basin (i.e. Agriculture in the upper reaches are economically more efficient.), while the lower-reach province applies it to the whole nation (i.e. Rice cultivation in the lower reaches is a national strategy). National strategy should be prioritized within a reasonable extent. However, the upper-reach provinces would never accept it if the lowerreach province makes no effort to improve the efficiency of water use with resting on the fact "national strategy." If the rice production is a national strategy, provision of subsidies from the national treasury should be considered. The compensation measures discussed in Table 3 may also be useful for this point.

\subsubsection{Reliability of data and information}

It is very difficult to reach consensus on water allocation since each province has doubts about data and information provided by other provinces. The first step to conflict solution is to build mutual confidence and accept data and information each other among provinces, thus the following measures should be taken:

- Each province shall make effort to obtain scientific/objective data and information so as to raise data transparency and to get other provinces to see that they are correct.

- Any data and information have to be open to the public so as to become able to be utilized and validated by experts, researchers and students.

- An organ that archives and controls statistical data and information provided by the provinces shall be established to check the validity of them. It must be independent from any provinces. 


\section{Collaborative and win-win approach}

\subsection{Simple model analysis for consensus building}

A collaborative and win-win approach is effective for solving the conflict, adopting not a majority rule but consensus building, which targets approval by all the members as much as possible, even though it takes relatively long time to reach a decision. Here a collaborative and win-win approach was considered utilizing a model simplifying the situation of the conflict among the provinces. The condition of the model is follows:

- Players: upper reaches and lower reaches

- Options of the players' action: to agree or to disagree with a water resources development in the upper reaches

- Profit/loss: A water resources development in the upper reaches can progress only when both the players choose agreement. Thus, if one player chooses disagreement, no water resources development is implemented and the water allocation remains as same as before.

The profit or loss of both the players on assumption of the three (3) cases of compensation is summarized in Table 4 .

Table 4: Profit or loss of players in the cases of compensation.

\begin{tabular}{|c|c|c|c|c|}
\hline \multirow{2}{*}{$\begin{array}{c}\text { Cases of } \\
\text { compensation }\end{array}$} & \multicolumn{2}{|c|}{ Player: Upper reaches } & \multicolumn{2}{|c|}{ Player: Lower reaches } \\
\hline & Agree & Disagree & Agree & Disagree \\
\hline $\begin{array}{c}\text { No } \\
\text { compensation }\end{array}$ & $\begin{array}{c}\text { Increase of water } \\
\text { allocation }\end{array}$ & \multirow{3}{*}{$\begin{array}{l}\text { Status quo } \\
\text { or } \\
\text { gradual } \\
\text { decrease of } \\
\text { water } \\
\text { allocation } \\
\text { as time } \\
\text { passes }\end{array}$} & $\begin{array}{c}\text { Decrease of } \\
\text { water allocation }\end{array}$ & \multirow{3}{*}{$\begin{array}{l}\text { Status quo } \\
\text { or } \\
\text { gradual } \\
\text { decrease of } \\
\text { water } \\
\text { allocation } \\
\text { as time } \\
\text { passes }\end{array}$} \\
\hline $\begin{array}{l}\text { Compensation } \\
\text { by } \\
\text { upper reaches }\end{array}$ & $\begin{array}{l}\text { Increase of water } \\
\text { allocation and pay } \\
\text { compensation to } \\
\text { lower reaches }\end{array}$ & & $\begin{array}{l}\text { Decrease of } \\
\text { water allocation } \\
\text { and get } \\
\text { compensation } \\
\text { from upper } \\
\text { reaches }\end{array}$ & \\
\hline $\begin{array}{l}\text { Compensation } \\
\text { by } \\
\text { a third party }\end{array}$ & $\begin{array}{c}\text { Increase of water } \\
\text { allocation }\end{array}$ & & $\begin{array}{c}\text { Decrease of } \\
\text { water allocation } \\
\text { and get } \\
\text { compensation } \\
\text { from a third } \\
\text { party }\end{array}$ & \\
\hline
\end{tabular}

In order to get the stakeholders to take seats at the negotiation table, it is necessary to convince them that they will get same or larger benefits with the consensus than those without the consensus. In the case of no compensation it is difficult for the lower reaches to agree because of no profit. As time goes by with no agreement, water allocation might virtually reduce for both the players because they would loss time benefit and suffer environmental deterioration.

This reveals the necessity to introduce some compensation system to start negotiation. Two types of compensation, those by the upper reaches and by a third party are discussed. In the case of compensation by the upper reaches, the 
lower reaches are easy to agree, but it may be difficult for the upper reaches to agree with payment of the compensation to the lower reaches, considering that there exists a confrontation between them. In the case of the compensation by a third party, both the players can easily get the negotiation table because of no losses by both of them. The third party who pays compensation is usually the central government or external donors.

Compensation does not necessarily have to be pecuniary. It can be anything that finally compensates the income of the lower reaches and can be accepted by both players. Such indirect compensation measures are:

- Development of industries and commercial business

- Investment in improvement of agricultural productivity

- Technical assistance on efficient water use, study of alternative water sources, and water balance simulation

\subsection{Result of the model analysis: collaborative and win-win approach}

The optimum choice for the lower reaches is to reach an agreement in earlier time. The same can be applied to the upper reaches considering the time factor even though it is less urgent. It should be noticed that this choice by the lower reaches does not mean a one-sided compromise. They would rather take a tactics of winning better conditions where they will take an initiative of the negotiation and realize better conditions in the agreement by applying this choice as soon as possible before the lower reaches finish a preparation for the negotiation.

If an agreement is made at an earlier stage, the upper reaches would avoid some losses of time value and virtual reduction of water use due to environmental deterioration. On the other hand, it is advisable that the upper reaches do not blame the lower reaches but take a tactics of leading the negotiation by making a proposal which the lower reaches can easily agree with.

It should be noticed that the important issue is not only whether the win-win approach is applied but also how the initiative can be demonstrated in such negotiations in terms and conditions [7].

\section{Principle of water resources development and management}

According to the evaluation in the study, the water resources potential and the present water uses almost balance in the Sefidrud River basin. It means that the water resources development potential has already reached the limits. Thus, new water resources development would hinder present water uses in the lower reaches, and may cause a conflict. Consequently, water resources would not be developed and the situation would deteriorate as mentioned in Section 6. For the time being, although a consensus of compensation has not been explicitlymade between the lower and upper reaches, the following measures were proposed in the stakeholder meetingas a kind of compensationmeasures and were agreed among the provinces.

The present irrigation efficiencies are rather low in the basin, namely $33 \%$ in traditional irrigation areas of the upper reaches and $42 \%$ in paddy fields of the 
lower reaches. It was discussed and estimated in the workshops that irrigation efficiency could be raised to $44 \%$ and $51 \%$ respectively in the target year of 2031 although they are lower than the government expectation of $50 \%$ and $55 \%$ respectively.

It is certain that water flow in the lower reaches would decrease when water resources would have been developed in the upper reaches. According to Section 6 , it would be necessary to compensate the reduction. Water saved through improvement of irrigation efficiency in both upper and lower reaches might be the compensation to the lower reaches. In this case, the improvement of the irrigation efficiency must be the duty of the upper-reach provinces that have water resources development plans, and the central government that has the power to finally approve the plans.

Employing the above condition, a numerical simulation was done to verify the water balance conditions, when the water resources development plans being proposed by the upper-reach provinces would be implemented, and when the irrigation efficiency would be improved to the target figures. It was identified that the sufficiency rate of the irrigation water to the demand in the upper reaches of Manjil Dam would be remarkably improved from about $60 \%$ to $80 \%$, and one in the lower reaches could remain around $90 \%$ until the target year of 2031.Although this scenario is not a simple task and requires considerable investment to improve irrigation efficiency, it is essential for effective development and fair allocation of limited resources as well as for the benefits to all the provinces.

Therefore, it was proposed as the principle rule that a new water resources development has to be carried out simultaneously with corresponding improvement of irrigation efficiency, so as not to hinder the downstream water uses and not to deteriorate the balance between the water resources potential and the water uses in the basin. Consequently, no conflicts on water allocation would be expected. This principle was basically accepted by all the relevant provinces.

It was identified essential that all the stakeholders make their effort to keep the above principle rule and coordinate plans on developing and saving water. It was proposed that a river basin organization (RBO) be established to build confidence each other and to cooperate and seek solutions with the collaborative and win-win approach.

\section{Conclusion}

The stakeholders gained confidence in the discussion process, and such momentum has been gathered that each province tries to cooperate for solving the overall problems. At least no members proposed to dissolve the stakeholder meeting. The river basin organization (RBO) would be developed by making the stakeholder meeting as a nucleus. Although the study initiated and facilitated the conflict management, there are still many issues to be overcome. For instance, it is necessary to deepen discussion matters such as scientific data collection and evaluation, proper basin modelling, planning and implementation through the IWRM concept, coordination and consensus building, and capacity development 
of the provinces, etc. It is also necessary to expand participants in the discussion. Farmers' representatives and environment watchers have to be at least added to discuss the improvement of tertiary or lower irrigation channels as well as issues on natural environment and water quality.

Over the past twenty years or so, proper water resources management has been planned and demonstrated in various river basins employing the IWRM concept. As Biswas [8] suggested, however, is such IWRM properly working? Overly many issues and subsectors have to be integrated and overly various interests cross each other. Thus, some misgivings come out that it might be difficult to coordinate and find some proper direction for IWRM.

In such circumstances, the conflict management is essential and has a possibility to be a key approach to realize the IWRM concept and the proper management of water resources and river basins.

\section{Acknowledgements}

This paper was based on the achievements and findings obtained in the course of the study [1], which was conducted as a technical cooperation program of JICA under the government of Japan. The authors would like to thank all those who participated in the preparation of data and evaluation as well as in the workshops and the stakeholder meetings. In particular, we thank the staff of the Regional Water Companies of the seven (7) provinces for their sincere efforts to the study.

\section{References}

[1] Japan International Cooperation Agency and Water Resources Management Company under Ministry of Energy of Iran, The Study on Integrated Water Resources Management for Sefidrud River Basin in the Islamic Republic of Iran, JICA, November 2010

[2] Yuka Suzuki, Conflict Management Approach, Jiyu Kokumin-sha, pp. $12-15,2008$

[3] Ian R. Calder, Blue Revolution: 2nd Edition -Integrated Land and Water Resource Management, EARTHSCAN, pp.269-271, 2005

[4] Hori Kimitoshi, Facilitation Skill Training, Toyo Keizai Shinpo-sha, pp.113, 2003

[5] Stephen McCaffrey, UN Convention on the Law of the Non-Navigational Uses of International Watercourses: Prospects and Pitfalls, World Bank Technical Paper, 1998

[6] Inoue Hidenori, Review on Principles of Equitable Utilization in International Disputes over Water Environment, Hosei University Repository, September 2005 (http://hdl.handle.net/10114/1366)

[7] Matsuura Masahiro, Study on Practical Negotiation: How to Build a Consensus, Chikuma Shinsho, April 2010

[8] Asit K. Biswas, Integrated Water Resources Management: Is It Working?, Water Resources Development, Vol. 24, No. 1, 5-22, March 2008 